\title{
A Study on the Determinants of Marketing Effectiveness of Mobile Marketing Communication on Social Media for Small and Medium Enterprises \& Neighborhood Stores' in USA
}

\author{
Dr Shajahan Shamsudeen \\ Ministry of Higher Education, Jazan University, \\ College of Business Administration.KSA \\ Nasser Khalufi \\ Ministry of Higher Education, Jazan University, \\ College of Business Administration.KSA
}

Prof.Shajahan Shamsudeen is a Management specialist from Wharton and HBS whose qualifications include MBA in Marketing and $\mathrm{PhD}$ in Marketing Management with Fellowship and Lectureship from University Grants Commission (UGC), New Delhi \& International Finance Corporation (IFC) Washington USA; having 19 years of Post-Doctoral Business Teaching experience including 5 Years in GCC as Full Time Professor, Ministry of Higher Education, Jazan University, College of Business Administration KSA\& Trainer for Quality Improvement Program for Faculty Development (QIPFD). He authored 16 text books in Management and published 290 research/conference papers, Chaired 35 international seminars and received 25 awards globally. He can be contacted drshamsudeen@jcba.edu.sa

Mr. Nasser Khalufi is the Lecturer in the Department of Marketing \& E commerce, CBA Jazan University also working as Marketing Counselor at the Innovation and Entrepreneurship Centre and Career advisor at the Training and Alumni unit of CBA. He was Post Graduated from Saint Xavier University, Chicago USA in MBA Internet and Social media Marketing.He has 5 years of teaching and industry experience. He can be contacted nkalofi@jcba.edu.sa

\section{ABSTRACT}

Purpose of the research was to ascertain the determinant of marketing effectiveness of SMEs and Neighborhood stores' mobile marketing communication on social media and to explore its contribution to customers' online and instore shopping experience. The study also portrayed customers' perception towards the mobile marketing message and its credibility as well. During data analysis, it was established that SMEs and Neighborhood stores which were using social media for Mobile marketing communications regularly as a part of their promotion strategy. The study findings predicted the marketing effectiveness of mobile marketing communication by resorting to Multiple Regression analysis. The study findings suggested that by focusing on mobile marketing content, message credibility, authenticity, its relevancy to weekly shopping along with human supports through chats and customer service (empathy) and consistent quality and performance ( Reliability) can give an edge to the SMEs and Neighborhood stores over national and global brands in their neighborhoods. Majority of the respondents commented that the mobile phone were the sole mate and companion in $24 \times 7$ mode in their life journey. The survey participants welcomed mobile marketing by the SMEs and Neighborhood stores through MMS, Push messages , Ringless voicemail, Location based services and Mobile Apps with credible message. Therefore, It is suggested that SMEs and Neighborhood stores should take advantage of study findings by predicting the marketing effectiveness of mobile marketing communication which influence the Marketing ROI of the firm and purchase intent of 
present and prospective customers while planning their weekly shopping online or instore.

Key Words: Mobile marketing Communication, Message credibility, Marketing effectiveness, Customers' perception and Empathy

\section{INTRODUCTION}

This study is all about mobile marketing communication and its marketing effectiveness among neighborhood communities in USA. The research was carried out to ascertain the customers perception on mobile marketing communications on social media by the SMEs and Neighborhood stores and its influence on their weekly online or offline (instore) shopping. As you are aware that shopping is an activity in which a customer browses the available goods or services presented by one or more retailers with the potential intent to purchase a suitable selection of them. Online shopping is a form of electronic commerce which allows consumers to directly buy goods or services from a seller over the Internet using a web browser. Consumers find a product of interest by visiting the website of the retailer directly or by searching among alternative vendors using a shopping search engine, which displays the same product's availability and pricing at different e-retailers (Hsiao, Ming-Hsiung 2009).

As of 2018, customers can shop online using a range of different computers and devices, including desktop computers, laptops, tablet computers and smartphones. A typical online store enables the customer to browse the firm's range of products and services, view photos or images of the products, along with information about the product specifications, features and prices. Online stores typically enable shoppers to use "search" features to find specific models, brands or items. Online customers must have access to the Internet and a valid method of payment in order to complete a transaction, such as a credit card, debit card, or a service such as PayPal. For physical products (e.g., paperback books or clothes), the e-tailer ships the products to the customer; for digital products, such as digital audio files of songs or software, the e-tailer typically sends the file to the customer over the Internet (KannanPK, AliceLi and Hongshuang, 2017).

According to Wikipedia Neighborhood store is generally defined spatially as convenient shop within a specific geographic area. The outlet operates in very friendly setting with face-toface social interactions, personal greetings and situations where residents seek to realize common business and cultural values, fair trade practices and maintain effective social control within the community. Neighborhoods have been the site of service delivery or "service interventions" in part as efforts to provide local, quality services, and to increase the degree of local control and ownership. In Canada and the United States, neighborhoods are often given official or semi-official status through neighborhood associations, neighborhood watches or block watches.

Neighborhood store is defined as a store specifically meant to fit in with its neighborhood surroundings and especially catering to the needs and desires of the local microcosm. For example, a salami shop in San Francisco's Little Italy is a perfect fit for its surroundings, while it would not blend in well in China town. Small and medium-sized enterprises (SMEs) are nonsubsidiary, independent firms which employ fewer than 500 employees. Here the authors took SMEs with FMCG production/manufacturing/marketing capabilities inside the neighborhood area chosen for the purpose of the study. It can be seen in USA that several voluntary social and consumer communities supports Neighborhood stores and patronage their products and services. Also SMEs connected with Neighborhood stores for marketing their products and services (Kahn AJ,1976).This study mainly focuses how consumer perceives their mobile marketing communications in the new age marketing with national and global brands and 
stores.

The transformations of the SMEs and Neighborhood stores begin with a deep understanding of the customers and a strategy to personalize their experiences at every point of interaction. The most appropriate technologies should be leveraged to enhance the experience in both the physical store and the digital world ( Bigne, Enrique 2005). Here the case in point is mobile marketing communications and customers perception on their message credibility through social media. Mobile marketing is defined as the interactive multichannel promotion of products or services for mobile phones and devices, smart phones and networks. Mobile marketing channels are diverse and include technology, trade shows or billboards. Globally, there are 3.3 billions of people who are using mobile phones for browsing the Internet and get in touch with other people. It can be stated that businesses need to start adopting mobile marketing efforts with message credibility in order to keep up their brand reputation and customer base with the advances in technology and market competition. In 2018, the mobile adaption rate increased up to 90 percent and internet penetration had already touched 75 percent mark in USA.

In this digital and interconnected world, marketing efforts are significant so that mobilefriendly operations can be done successfully. According to Leppäniemi Matti (2008), people spend up to 5-15 hours a day from their time on mobile phones. Nearly 2.2 billion people has enrolled in the Facebook in early 2018 and accepted as their major platform for expressing and sharing their feelings and lively happenings. Every 60 seconds on Facebook 510,000 comments are posted, 293,000 statuses are updated, and 136,000 photos are uploaded. One in five page views in the United States occurs on Facebook. Mobile marketing is the fast growing communication industry segments that are transforming the integrated marketing communication with an eye on customization for every global citizen.

According to the Groupe Special Mobile Association (GSMA) data report (2017), in all over the world, there are almost 7.8 billion SIM card connections and out of which 57 per cent are smart phones. The GSMA Mobile Economy series provided the latest insights on the state of the mobile industry worldwide revealed that there were 5.05 billion subscribers, 3.3 billion mobile internet users, 29 million 4G customers,7.8 billion Total connections in 2017. Again it predicted 5.9 billion subscribers, 5.05 billion mobile internet users, 1.29 billion $4 \mathrm{G}$ customers, 25.1 billion Total connections by 2025 . The contribution of the mobile phone sector to world GDP would increase from USD 3.6 trillion in 2017 to USD 4.6 trillion in 2025. The GSMA report projected a bright future as mobiles market would experience a massive growth in mobile application, data, voice call and internet usage.

In mobile marketing, the most popular mode of communication is SMS Marketing. Marketing through cell phones' SMS (Short Message Service) became increasingly popular in the early 2000s in USA when businesses started to collect mobile phone numbers and send off marketing communication messages. Another form of mobile marketing is MMS Marketing. MMS mobile marketing can contain a timed slideshow of images, text, audio and video. This mobile content is delivered via MMS (Multimedia Message Service). Nearly all new phones produced with a color screen are capable of sending and receiving standard MMS message. Brands are able to both send (mobile terminated) and receive (mobile originated) rich content through MMS A2P (application-to-person) mobile networks to mobile subscribers.

Again Push notification is a message that pops up on a mobile device. It is the delivery of information from a software application to a computing device without any request from the 
client or the user. They look like SMS notifications but they are reached only the users who installed the app. The specifications vary for iOS and android users. SMS and push notifications can be part of a well-developed inbound mobile marketing strategy. With the strong growth in the use of smartphones, app usage has also greatly increased. Therefore, mobile marketers have increasingly taken advantage of smartphone apps as a marketing resource. Marketers aim to optimize the visibility of an app in a store, which will maximize the number of downloads. This practice is called App Store Optimization. With the fast progress and growth of the smartphone market, high-quality Mobile app development is essential to obtain a strong position in a mobile app store. Besides Apps, QR codes allow mobile phone owners to visit a web site address by scanning a digitized 2D image with their phone's camera. Mobile marketing via proximity systems, or proximity marketing, relies on GSM 03.41 which defines the Short Message Service - Cell Broadcast. Location-based services (LBS) are offered by some cell phone networks as a way to send custom advertising and other information to cell-phone subscribers based on their current location (Banerjee, Syagnik (Sy) and Dholakia, Ruby Roy, 2008). The advancement of mobile technologies has allowed the ability to leave a voice mail message on a mobile phone without ringing the line. This is called Ringless voicemail. By optimizing the technology, marketers can utilize the process to increase engagement of their product or service (Gaughan L, 2012).

Due to the demands for more user controlled media, mobile messaging infrastructure providers have responded by developing architectures that offer applications to operators with more freedom for the users, as opposed to the network-controlled media. Along with these advances to user-controlled Mobile Messaging 2.0, blog events throughout the world have been implemented in order to launch popularity in the latest advances in mobile technology. In short, various Mobile technologies, Apps and Platforms provided opportunities for customers to buy products and services online after comparing their prices with similar brands and outlets. For companies that utilized mobile marketing, provided opportunities that increased their sales and profit in the short and long run(Shajahan S,2006) . Many researchers claimed that social media marketing provided a huge benefit for an organization in terms of their brand equity, brand recall, customer connectivity and message credibility (Abhishek Borah, Gerard J Telli and Halo, 2016).Therefore, this study examined the role of SMEs and Neighborhood stores mobile marketing communications on social media extensively and their message credibility. This has reflected on their respective marketing effectiveness and total customer experience of the online and offline shoppers in USA.

Mobile marketing communication has become more and more popular in USA. However, some mobile marketing communication is sent without a required permission from the consumer causing privacy violations. It should be understood that irrespective of how well marketing communication messages are designed and how many additional possibilities they provide, if consumers do not have confidence that their privacy will be protected, this will hinder their widespread deployment. But if the marketing communication messages originate from a source where the user is enrolled in a relationship/loyalty program, privacy is not considered violated and even interruptions can generate goodwill (Ström R, Vendel M \& Bredican J, 2014). It may be noted with caution that mobile devices are intimately personal and are always with the user, and four major concerns can be identified: mobile spam, personal identification, location information and wireless security. Further Aggregate presence of mobile phone users could be tracked in a privacy-preserving fashion (Cleff Evelyne Beatrix, 2007).

\section{LITERATURE REVIEW}

The concept of marketing effectiveness first came to prominence in the 1990s with the publication of Improving Marketing Effectiveness (Shaw R, 1998). This study was based on 
exploring the marketing effectiveness of mobile marketing communication of SMEs and Neighborhood stores on social media networks and its impact on customers' experience while shopping. Mobile phone companies had adopted new technologies for modifying their handsets and operational feature for easily accessing different social media sites from the opening screen itself. Respondents of the study used different types of social media sites on their mobile phones such as Facebook,YouTube, WhatsApp and Twitter on which they can regularly face ads for the products and services from different service providers and Neighborhood outlets.

It may be noted the growing power of social media like Facebook globally. Worldwide, there are over 2.20 billion monthly active Facebook users for Q1 2018. Further, Five new profiles are created every second on Facebook globally. On average, the Like and Share Buttons are viewed across almost 10 million websites daily. Photo uploads total 300 million per day on Facebook. Average time spent per Facebook visit is 20 minutes in USA. Many mobile users used mobile phones for purchasing the products and services via the Internet in all over the world. Also, there is an increase in the trend of mobile marketing through social media sites. Kim YH, Kim J \& Wachter (2013), suggested that marketing can be integrated with mobile marketing which led to positive effects on the businesses and profit margin. Through mobile marketing, SMEs and Neighborhood stores can efficiently provide customers with timely and vital information with the use of social media platforms. On Facebook, YouTube, Twitter, and company websites, customers also get different choices for selecting the right product with brand and price comparisons and relative benefits of each purchase. Ström R, Vendel M \&Bredican J (2014) in their study mentioned that during pre purchase stage and information gathering on intended products and services, customers analyzed the previous customer reviews on a particular product or service of SMEs and Neighborhood stores . This would help quickly to make a purchase decision on those brands.

Kaplan, Andreas (2012) categorized mobile marketing along the degree of consumer knowledge and the trigger of communication into four groups: strangers, groupies, victims, and patrons. Consumer knowledge can be high or low and according to its degree organizations can customize their messages to each individual user, similar to the idea of oneto-one marketing. Regarding the trigger of communication, Kaplan differentiates between push communication, initiated by the organization, and pull communication, initiated by the consumer. Within the first group (low knowledge/push), organizations broadcast a general message to a large number of mobile users. Given that the organization cannot know which customers have ultimately been reached by the message, this group is referred to as "strangers". Within the second group (low knowledge/pull), customers opt to receive information but do not identify themselves when doing so. The organization therefore does not know which specific clients it is dealing with exactly, which is why this cohort is called "groupies". In the third group (high knowledge/push) referred to as "victims", organizations know their customers and can send them messages and information without first asking permission. The last group (high knowledge/pull), the "patrons" covers situations where customers actively give permission to be contacted and provide personal information about themselves, which allows for one-to-one communication without running the risk of annoying them.

Now SMEs and Neighborhood stores use social media sites for various purposes such as to keep up to date with customers and make them informed and aware of arrival of new products and services. Moreover, with the use of social networking sites, they can effectively address the issues and problems of customers which they are facing related to products or services and 
resolve them 24/7. Lamberton C \& Stephen AT (2016), stated that most of SMEs and Neighborhood stores were taking advantages of social media and proximity marketing for turning a neutral or negative experience into a positive one and shared with all customers. It is suggested that SMEs and Neighborhood stores can easily accomplish success if it effectively uses the mobile marketing with credible messages for grabbing the attention of a large number of customers.

If involvement of the customer in shopping or purchase is higher, customers take more notice of the retail firm's communications and can thus form an opinion more easily (Zaichkowsky and Judith Lynne, 1985) . On the other hand, customers with low involvement only perceive a firm's communications subliminally or to a limited extent because, that is they are less interested in the retailer or the retail sector concerned and what it has to offer. The phrase 'positive shopping experience" has become a slogan for companies large and small in their never-ending efforts to attract and retain loyal and profitable customers online and offline (Shajahan S, 2006 \&2010). The reason is obvious: a positive customer experience is a marketplace differential for any company seeking to distinguish itself from competitors ( $\mathrm{S}$ Shamsudeen 2016,2017a,b\&c ). This is also true for the SMEs and Neighborhood stores in USA.

According to Bosomworth, (2015), getting benefits of mobile marketing cannot be possible without the help of mobile phone Android Apps freely available in the Google PlayStore and websites. It is a cost-efficient process where the SMEs and Neighborhood stores do not have to spend money every time during promotional activities. Also, they can directly reach to the customers on mobile marketing because they are reasonably affordable .Moreover, Mobile marketing on social media helped SMEs and Neighborhood stores to connect their customers on a $24 \times 7$ mode at a low cost as compared to TV, Print and radio message vehicles.

Lamberton C \& Stephen AT (2016), argued that mobile marketing did not have a particular standard for their operation like computers and laptops because it has different shapes, sizes, screen, battery, and resolution based on the handsets which the customers use. In addition, the quality of mobile phone was totally based on its operating system and other compatible features which are essentially not the same for every advertisement message. According to Shankar, Kleijnen\& Morrissey (2016) from time to time, upgradation facility on mobile phone makes the mobile capacity very low and very slow. In addition, it is difficult for the users to deal with it and to operate features and to performed functions online and the dependency made on the mobile phone's compatibility, technology, and features.

Watson C McCarthy \& Rowley( 2013 ) observed that mobile marketing has changed the attitude and perception of customers toward the social media marketing. It becomes more convenience for the people to make a purchase online if they are unable to visit stores for making a purchase. It benefits the customer because they can easily get products and services of their choice quickly on the internet with home delivery. A convenience orientation is a key benefit that shoppers seek in the modern environment. Consumers' perceptions of convenience (e.g., opening hours, location, parking, online order and home delivery) will have a positive influence on their satisfaction with the service (Thompson and Donald L 1967). Consumers' perceived expenditure of time and effort interacts to influence their perceptions of service convenience, and retail facilities are designed to affect those time and effort perceptions. For example, a central location can reduce the transaction costs associated with shopping like transportation cost, time spent and so on(Shajahan S, 2001\&2005). Here the credibility of the message in the advertisement through mobile marketing is depending on credence of the service provider (SMEs and Neighborhood stores), their brand equity and previous shopping experience ( online or offline) of the customers. 
In mobile marketing and online shopping there are options to make payment online or cash on delivery. Apart from this, customers can easily compare one company product with other companies' product and make a decision of purchasing. According to the view of Strom, Vendel and Bredican (2014), SMEs and Neighborhood stores strive to build a relationship with the customers by using mobile marketing. Samaha, Beck and Palmatier (2014) observed that SMEs and Neighborhood stores create websites and mobile apps that help them stay connected with customers for 365 days annually .It is also stated that social media changes the perception of customers toward to advertisements of SMEs and Neighborhood stores. Many people are highly influenced by the credible messages which are posted by the SMEs and Neighborhood stores on the social media sites in USA. Many people believe on the information, product/service review, and customers' feedback which are provided to customers on the internet site. Here the case in point is SMEs and Neighborhood stores and their propensity to go for bait advertisement (seems to be ) in mobile marketing. Further the authors made an attempt to study the customer's perception on credibility of the mobile marketing message and its marketing effectiveness.

\section{DEFINITON OF VARIABLES}

Marketing effectiveness is the measure of how effective a given marketer's go to market strategy towards meeting the goal of maximizing their marketing spending to achieve positive results in both the short- and long-term. It is also related to Return On Marketing Investment (ROMI). This Value can be significantly enhance through proper go to market communication strategy (AP\&QC,2001). At the program level marketers can improve their effectiveness by managing and executing each of their marketing campaigns better. It's commonly known that consistency of a Marketing Creative strategy across various media (e.g. TV, Radio, Mobile, Print and Online), not just within each individual media message, can amplify and enhance impact of the overall marketing campaign effort(Lenskold James, 2003). Additional examples would be improving direct mail through a better call-to-action or editing web site content to improve its organic search results, marketers can improve their marketing effectiveness for each type of program.

A growing area of interest within (Marketing Strategy) and Execution are the more recent interaction dynamics of traditional marketing (e.g. TV or Events) with online consumer activity like Social Media(Powell, Guy R, 2005). Here the case in point is mobile marketing communication of SMEs and Neighborhood stores through social media. It may be noted that marketing effectiveness of mobile marketing communication through social media is taken as dependable variable for the purpose of the study. While predicting the marketing effectiveness of Mobile marketing communication, it could be seen that sales revenue from both online and instore purchases coupled with communication impact as reflected in their perception towards the Mobile marketing message content, authenticity and credibility of the SMEs and Neighborhood stores (Guo S, Wang M, and Leskovec J, 2011).

Here the authors considered mobile marketing communication was a part of business promotion and a customer service wherein SMEs and Neighborhood stores were informing the arrival of their products and services with latest offers/discounts, persuading and motivating the customers to go for shopping online or offline. Hence the elements of online shopping and instore visit came into the research scenario as well. This is because respondents of the study were from the neighborhood and were considered as a part of local community. Further respondents preferred both online and offline/instore purchases. 
According to Zeitmal, Berry and Parashuraman the criteria used by consumers in evaluating service quality can be consolidated under five broad categories. They are (1)Tangibles means appearance of physical elements, (2) Reliability means dependable, accurate performance, (3) Responsiveness means promptness and helpfulness, (4) Assurance means competence, courtesy, credibility and security and (5 ) Empathy means easy access ,good communication and customer understanding( Shajahan S, 2004a \&2016). Here the final action of the mobile marketing communication is taken by way of considering shopping experience of the respondents online and offline into consideration and included six dependable variables for the purpose of the study. They were (1)Search and compare products ,price \& brands online, (2)Mobile marketing message content and its relevancy to weekly shopping, (3)Mobile marketing message credibility, authenticity and Empathy (4) Assurance, (5) Responsiveness and (6) Reliability.

Here the authors defined credibility as trust worthiness, believability and honesty of the mobile advertiser. Further, Responsiveness means propmtness and helpfulness both online and instore. In simple terms it is defined as the willingness to help customers and provide them with prompt services both online and instore. Empathy means easy access, good communication and customer understanding both online and instore. Assurance means competence, courtesy, credibility and security both online and instore. Finally, Reliability means dependable, accurate performance both online and instore.

\section{ABOUT THE STUDY}

It can be seen that mobile phone users utilized their handsets for internet service to access social platforms. Apart from this, many mobile users in USA were using the Internet for the purpose of gaming, visiting social media sites, and shopping . Out of 264 million North American regions internet subscribers $3 \mathrm{G}$ and $4 \mathrm{G}$ technologies contributed 24 and 47 percent respectively in 2017. Again, GSMA forecasted the potential of touching 328 million subscriber bases with penetration rate of 80 percent in 2025 as against the bench marked penetration rate of 73 per cent in 2017. Hence it is suggested that online and offline customers with or without the support of physical stores can contribute various companies bottom lines in a least costly yet most profitable manner. This study was focused more on middle income group with annual income of USD 2 to 3 lakh and screened their perceptions towards their message credibility of SMEs and neighborhood stores mobile advertisements. It is established that online customers must have access to the Internet and a valid method of payment in order to complete a transaction. Generally, higher levels of education and personal income correspond to more favorable perceptions of shopping online. Increased exposure to technology also increases the probability of developing favorable attitudes towards new shopping channels( Bigne, Enrique, 2005).

The fundamental reason for this study was how far Small and Medium Enterprises (SME) and Neighborhood stores utilized the new age marketing communication channels for connecting with their profitable customers effectively with credible offers and valuable messages. Further 20 percent of the customers contribute 80 per cent of the profit of any business in USA. However, it is widely accused SMEs and Neighborhood stores for bait advertisement in USA for their unethical business practices. It can be seen that Bait advertising is an unethical advertising technique that involves luring the customer in with a promise of a sale or an inexpensive item they may be interested in, and once capturing their attention, the online advertiser changes the scheme by making the product unavailable and then directing the consumer to a like product that is more expensive. An online vendor or merchant will offer the pseudo sale either in an online advertisement or newsletter and this is illegal and banned in USA. However, authors screened such messages which appear to be in the nature of bait 
advertisement during peak business and shopping periods for the purpose of the study.

The sample size selected for the study was 1500 and the questions were emailed to the respondents. Convenient sampling method was resorted to the purpose of the study. The period of the study was eight months starting from May 2017.Nearly 95 percent of the chosen customers were completed the survey with 1 to 3 reminders within 3 months of posting the questionnaire. Non-response of the respondents was compensated by posting the questionnaires to the new customers from the same population till the authors received the adequate sample size.

The underlying assumption of the study is that the shopper travels from home to the closest store of the selected chain, and then returns home. In reality, shoppers may reduce their travel time by linking shopping trips together or combining store visits with other required travel. "Trip chaining," as this practice is called , results in shoppers requiring less than the measured travel time to make a store visit and possibly shopping more than expected at distant stores. Retail location theory indicates that consumers prefer to shop as close to home as possible, all other things being equal (Thompson and Donald L,1967). The extent to which consumers are willing to travel to a shopping centre outside the local trading area, then, is inversely related to the extent to which the local shopping centres fulfill their shopping needs (Shajahan S 2016b,2017a,b \&c).

Previous research found that two fundamental motivational orientations were behind the different shopping motives. The first motivational orientation (e.g., economic, utilitarian) involves consumers engaging in shopping out of necessity to obtain needed products, services, or information with little or no inherent satisfaction derived from the shopping activity itself. This motivational orientation is referred to as the "task-oriented motivational orientation. Mobile marketing provided the best input for them with credible message (Karjaluoto Heikki \& Leppäniemi Matti, 2005) and hence variable 2 and 4 selected for the study are more relevant in the neighborhood stores context (Table -1 given under 4.1 in the next page).

As the revenues from online sales continued to grow significantly researchers identified different types of online shoppers, Rohm,AndrewJ \&Swaminathan,Vanitha (2004) identified four categories and named them "convenience shoppers, variety seekers, balanced buyers, and store-oriented shoppers". They focused on shopping motivations and found that the variety of products available and the perceived convenience of the buying online experience were significant motivating factors. This was different for offline shoppers, who were more motivated by time saving and recreational motives (Shajahan S, 2001, 2004 b\&c). The other motivational orientation (e.g., recreational, hedonic) describes consumers engaging in offline shopping to derive inherent satisfaction from the shopping activity itself. The shopping activity is freely chosen, without any need to engage in it This motivational orientation is referred to as the "recreational motivational orientation"( Parker, Christopher J 2016) The study found that motivation decreased offline purchasing intentions and spending in neighborhood stores. So online shopping and mobile marketing provide a better solution for the service providers.

\section{Relationship between the variables and the mobile marketing effectiveness}

The marketing around the digital environment, customer's buying behaviour may not be influenced and controlled by the brand and firm, when they make a buying decision that might concern the interactions with search engine, recommendations, online reviews and other information. With the quickly separate of the digital devices environment, people are more likely to use their mobile phones, computers, tablets and other digital devices to gather 
information. In other words, the digital environment has a growing effect on consumer's mind and buying behaviour. In an online shopping environment, interactive decision may have an influence on aid customer decision making. Each customer is becoming more interactive, and though online reviews customers can influence other potential buyers' behaviors (Kawai Fand Tag S 2017,YadavM, JoshiY \&RahmanZ, 2015 and Novak Thomas P, Donna L Hofmann and YiuFai Yung, 2000) .

In order to study the relationship among the six independent variables selected for predicting the marketing effectiveness of mobile marketing communication through social media , multiitem scales were used. A multi-item scale consists of a number of ratings combined into a single value. Multi-item 103 scales are used to represent complex psychological constructs that can't be summarized in a single question. Multi-item measures are more reliable and less volatile than single-item questions. As a result of this increased stability, multi-item scales make excellent benchmarks (Henning 2009, Nunnally JC and Berstein IH ,1994 Malhotra Naresh and David Birks,2007, Novak Thomas P, Donna L Hofmann and Yiu-Fai Yung 2000 and Shajahan S,2004a,2009\&2011).

The internal consistency of the independent variable is an important test of reliability. Reliability test is used to assess the internal consistency of summated scale where several items are summated to form total score. One measure of internal consistency is Cronbach alpha. Cronbach's alpha accounts for all possible two-way splits (Nunnally 1967 and Shajahan S, 2004a, 2009\&2011). The Cronbach alpha < 0.6 indicates poor reliability. The Cronbach alpha $>0.7$ indicates more reliability (Nunnally \& Berstein 1994). Table 1 gives the Cronbach alpha values for the constructs..

Table 1 Cronbach Alpha Values of The Variables

\begin{tabular}{|l|l|l|}
\hline Sl no & Independent Variable & Cronbach alpha \\
\hline 1 & $\begin{array}{l}\text { Search and compare products, price \& } \\
\text { brands online }\end{array}$ & 0.896 \\
\hline 2 & $\begin{array}{l}\text { Mobile marketing message content and } \\
\text { its relevancy to weekly shopping }\end{array}$ & 0.803 \\
\hline 3 & $\begin{array}{l}\text { Responsiveness (propmtness and } \\
\text { helpfulness both online and instore) }\end{array}$ & 0.789 \\
\hline 4 & $\begin{array}{l}\text { Mobile marketing message credibility, } \\
\text { authenticity and Empathy (easy access, } \\
\text { good communication and customer } \\
\text { understanding both online and instore) }\end{array}$ & 0.843 \\
\hline 5 & $\begin{array}{l}\text { Assurance (competence, courtesy, } \\
\text { credibility and security both online and } \\
\text { instore) }\end{array}$ & 0.890 \\
\hline 6 & $\begin{array}{l}\text { Reliability (dependable, accurate } \\
\text { performance both online and instore) }\end{array}$ & 0.791 \\
\hline
\end{tabular}

Source: Sample Survey December 2017

It is seen from the Table- 1 given above that the values are in the range 0.789 to 0.896 which indicate that the instruments are reliable Among the effective integrated marketing communication strategies, mobile marketing communication through SMS, MMS and social media were considered as useful tools which assisted the company in connecting their valuable customers effectively for promoting and marketing products and services online and offline/stores. As the authors observed from the responses, most of the customers preferred to buy products and services online instead of purchasing from a physical store. In this regard, it is essential for the firm to focus on the message credibility of SMEs and Neighborhood stores mobile marketing communications and customers experiences during shopping. 


\section{Significance of the study}

Mobile marketing is gaining a lot of importance since many SMEs and Neighborhood stores are keen to setup their footprints in the area chosen for the study. Online retailers has place much emphasis on customer trust aspect, trust is another way driving customer's behaviour in digital environment, which can depend on customer's attitude and expectation. Indeed, the company's products design or ideas can not met customer's expectations. Customer's purchase intension based on rational expectations, and additionally impacts on emotional trust. Moreover, those expectations can be also established on the product information and revision from others (Leppäniemi Matti, 2008).

This study can make a significant contribution to understand the customer perception on bait advertisement and message credibility in mobile marketing of SMEs and neighborhood stores in USA. Intense competition among the large firms, SMEs and Neighborhood stores offered a wide array of choices for the customer to shop with and hence there arises a need for studying the customer perception of Mobile marketing and its message credibility which can provide a superior marketing effectiveness and customer experience during online and offline shopping. Obtaining and sustaining a competitive advantage in retailing, specifically in US retail environment today sets the challenge to determine one differentiating variable that will position SMEs and Neighborhood stores differently from industry leaders like Wal-Mart Inc ( having USD 500.04 billion sales revenue annually with 2.3 million associates and 270 million weekly shoppers in their stores in 2018) in their minds. Retail establishments worldwide are trying to find that sustainable competitive advantage and it currently seems possible by strategically focusing on customer experience both online and offline and their perception of mobile marketing communications on their total experience during shopping.

\section{Problem statement}

In the book What Sticks, authors Rex Briggs and Greg Stuart (2006) calculated that marketers waste $37 \%$ of their marketing investment. Reasons for the waste include failure to understand underlying customer motivations for buying, ineffective messages and inefficient media mix investment .So the marketing effectiveness of marketing communication is very important for MROI. Further, the scarcity of scholarly research on the perception of mobile marketing communication on social media and online purchase calls for a theory-based framework to examine marketing effectiveness holistically (Shankar V, Kleijnen M, Ramanathan S, Rizley R, Holland \& Morrissey, 2016 and Peterson RA, Balasubramanian S and Bronnenberg BJ,1997). The research problem, therefore, is to compound the perception of online and offline shoppers towards mobile marketing communication of SMEs and Neighborhood stores on social media and its marketing effectiveness in USA.

\section{Research questions}

Customer considered switching between e-channels, because they were mainly influenced by the comparison with offline shopping, involving growth of security, financial and performancerisks In other words, and a customer shopping online that they may receive more risk than people shopping in stores. Trust is another factor to be considered in this regard (Pappas $\mathrm{N}$, 2016 and Guo S, Wang M,\& Leskovec J, 2011 ). There were three factors might influenced their buying decision, firstly, people could not examine whether the product satisfied their needs and wants before they received it. Secondly, customer might concern at after-sale services. Finally, customer might afraid that they could not fully understand the language used in esales. Based on those factors customer perceived risk might be significantly influenced their online purchasing behaviour ( Sherry Y Chen en \& Robert D.Macredie, 2005). Hence the major research questions addressed during the study were as follows: 
i. What were the customer's perceptions of using social media platform for marketing products and services of SMEs and Neighborhood stores in USA?

ii. How does SMEs and Neighborhood stores mobile marketing communication benefit costumers? and

iii. What were the most popular type of mobile marketing communications and their message credibility and authenticity among active shoppers in USA

\section{Research objectives}

The focus of the study was to find out the determinants o marketing effectiveness of mobile marketing communication on social media by SMEs and Neighborhood stores and its contribution to the customers' online and offline shopping experience. Hence the major Objectives of the study were as follows:

i. To evaluate the customers' perception on mobile marketing communication on social media by SMEs and Neighborhood stores in USA.

ii. To predict the determinants of marketing effectiveness of mobile marketing communications of SMEs and Neighborhood stores on social media and

iii. To find out the most preferred type of mobile marketing communication, its message credibility and authenticity among shoppers in USA.

\section{Scope of the study}

Customers were attracted to online shopping not only because of high levels of convenience, but also because of broader selections, competitive pricing, and greater access to information. Business organizations seek to offer online shopping not only because it is of much lower cost compared to bricks and mortar stores, but also because it offers access to a worldwide market, increases customer value, and builds sustainable capabilities. However this current study focused exclusively on the SMEs and Neighborhood stores in USA. This study was conducted in the cross section of USA comprising of Adams County, Alexander County, Brown County, Champaign County, Clinton County, Douglas County, Effingham County, Ford County, Hamilton County, Jackson County, Lake County, Madison County, Scott County, Washington County Woodford County, Illinois, Indiana, , Chicago city, California, Santa Clara and San Jose Airport area .The population of the study was confined only to present and past(within one year ) customers of SMEs and Neighborhood stores in the region chosen for the study. Period of the study was from May to December 2017.

\section{RESEARCH PROCESS}

Primary data were obtained from customers who visited the SMEs and Neighborhood stores in the region chosen for the study by means of administering the structured questionnaire online. The survey questionnaire consists of two parts: part-A and part-B. Part-A consists of questions connected to respondent's socio-economic and demographic profile. The responses are measured using nominal scales. Part- B consists of the items for customer experience, each dimension of the determinants and the moderators. All items are measured on 5-point Likert scale (5 "strongly agree" to 1 "strongly disagree"). Testing of the preliminary questionnaire was carried out in March 2017 using convenience sample of 150 respondents. The internal consistency of the instrument was tested through reliability analysis using Cronbach's alpha. All reliability results were in the range 0.791 to 0.896 which exceeds 0.70 limit of acceptability (Table-1). The respondents who were part of the pilot study did not participate in the final survey. The population to be considered for this study consists of customers between the age group of 19 and 60, who have shopped online and offline of SMEs and Neighborhood stores in the region chosen for the study within 12 months. Therefore, the population can be defined as active online and offline retail shoppers. Respondent for the study is a person who does shopping within a year in the region chosen for the purpose of the study. 
Convenience sampling, a method of non probability sampling is opted for this particular study. This is a type of sampling where the first available primary data source will be used for the research without additional requirements. It also relies on data collection from population members who are conveniently available to participate in study. Invitations to participate in the survey were emailed with online link to the selected respondents. Then respondents were contacted online chats and social media posting and were requested to complete the questionnaire on time. Sufficient time was given and the completed questionnaire. The main online survey was completed with 1800 responses and 1500 responses were found to be complete after applying Outliers. More responses were obtained in the month of November and December 2017 with the follow up of email requests and voice and text message reminders of the survey. Data that had collected online were divided into two sections - data regarding the demographic profile of the respondents and data regarding the influence of the six variables on the customer's perception on mobile marketing and its message credibility. The collected data were coded in an SPSS spreadsheet and a simple statistical analysis such as frequency distribution and percentage was carried out along with multiple regression models. SPSS-16 was used for the analysis of data. Reliability, the degree of consistency between multiple measures of a particular construct is tested using Cronbach's alpha coefficient. Large tolerance values and variance inflation factors were observed, indicating no issues with multicollinearity (Hair et al 2006 \& Shajahan S 2004a, 2009 \&2011)

Authors employed both quantitative and qualitative research methods for exploring the role of mobile marketing communication on social media and its contribution to customers' experience during online and offline shopping. The rationale behind using these techniques was that both of them helped developing deeper understanding related to the topic with the support of Internet. Further, inductive research approach would helped the authors to carry out the research investigation and research process by gathering profile information for the active customers initially from the SMEs, Neighborhood stores and Google Analytics and then segregated the sample for the purpose of the research. Furthermore, by making use of both primary and secondary data on active customer profiles and RFM analysis supported the basis of drawing the suitable sample size with adequate representation from the population for the purpose of the study.

Again, authors adopted descriptive research design for the purpose of the research. The rationale behind this selection was to represent Activities, Interest and Opinion (AIO) along with purchase intentions of the respondents included in the research would be helpful for deeper understanding of American middle class and their regular/routine shopping habits (Novak, Thomas P, Donna L Hofmann and Yiu-Fai Yung, 2000). Thus, the research design opted for the study was supporting for extracting a valid outcome in line with objectives set for the purpose of the study. In this study authors adopted convenient sampling method for collecting the data from 1500 respondents through online survey backed with emailing the questionnaire. During data analysis were undertaken by applying multivariate analysis such as multiple regression with the use of SPSS.

Ethics need to be considered while carrying out the survey research in US context. In addition, it is important to focus ethically while requesting / approaching the customers for participating in the survey. The purpose and aim of the research should be made clear to them without an iota of doubt. Also, their profile information would be used for the purpose of this study and kept confidentially as per the USA academic research community guidelines. It may be noted that no respondents were forced to take part in this survey and the respondents of 
the survey accepted authors declaration and privacy statement by honoring US laws and respondents rights.

Apart from the ethical considerations, the information which was gathered from secondary sources cited accurately at the end of the paper by honoring Section 107 of the Copyright Act of USA under fair use. It assisted the authors to meet the aim and objectives of the research successfully by drawing meaningful inferences, useful conclusion and valid suggestions/policy implications without any violations of USA laws and breaches of research ethics.

\section{LIMITATIONS OF THE STUDY}

Limitation of this study is the non-probability sampling technique used to collect data from the respondents. Usage of a non-probability sample compromises the external validity of a study to a large extent. Therefore, it is advisable to repeat this study with a probability sampling technique. The period of the study was only 8 months and with limited resources at disposal of the authors was also considered as limitations of the study. The study was confined only to SMEs and Neighborhood stores of 3 Western States of USA. Therefore, it is advisable to repeat this study with more states from other parts such as northern, southern and eastern parts of USA.

\section{DATA ANALYSIS AND INTERPRETATION}

Following three sections describes various analyses with research implications

\section{Demographic Profile of the Respondents}

Gender wise, majority of the respondents were males (78\%). A majority of the respondents were between the age group of 19-29 years (45\%). Married respondents were more when compared to the other categories (65\%). Nearly 55 percent of the families had 4 members. Majority of the families (65\%) had two earning members showing that the disposable income has increased. In the occupation category, most of the respondents were employees in private organizations (65\%).It is implied from the figure1 given below that 19-29 years old respondents (45 per cent) followed by 30-39 years old respondents (25\%) were participated in the study as the authors were chosen convenience sampling among active shoppers of the SMEs and Neighborhood stores.

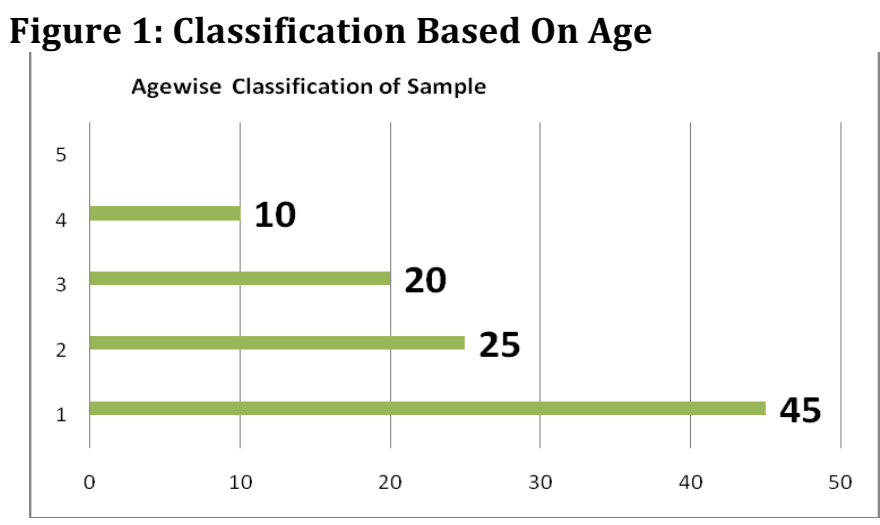

Source: Sample Survey December 2017

Figures in Per Cent only

Here in Y axis represent series 1 with age group between 19-29, series 2 with age group between 30-39, series 3 with age group between 40-49 and series 4 with age group 50 and above. 
Figure 2: Educational Level of The Sample

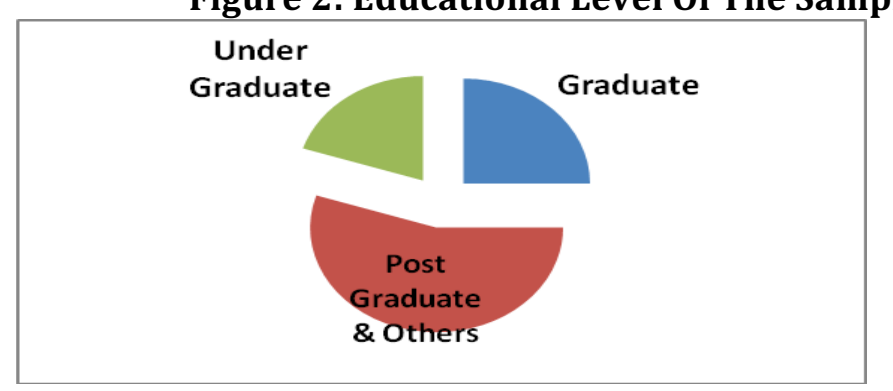

Source: Sample Survey December 2017

It is implied from the figure 2 given above that PG holders, PhDs and PG Diplomas dominate the sample with 55 per cent followed by Graduates (25\%). They were more accessible for the purpose of the study and also reflect the active chunk of highly educated and young active shoppers of SMEs and Neighborhood stores.

It is implied from the figure 3 given below that respondents with monthly income up to USD 10,000 dominated the sample with 40 per cent followed by respondents with USD 10,00120000 and USD 30,001-40000 (20\% each) as the researchers were chosen convenient sampling. In short, Respondents were highly educated since majority of them were Post Graduates and professionals ( $80 \%$ ). A majority of the respondents were drawing a salary upto USD 200,000 annually (60\%).

Figure 3: Monthly Income Of Sample Population

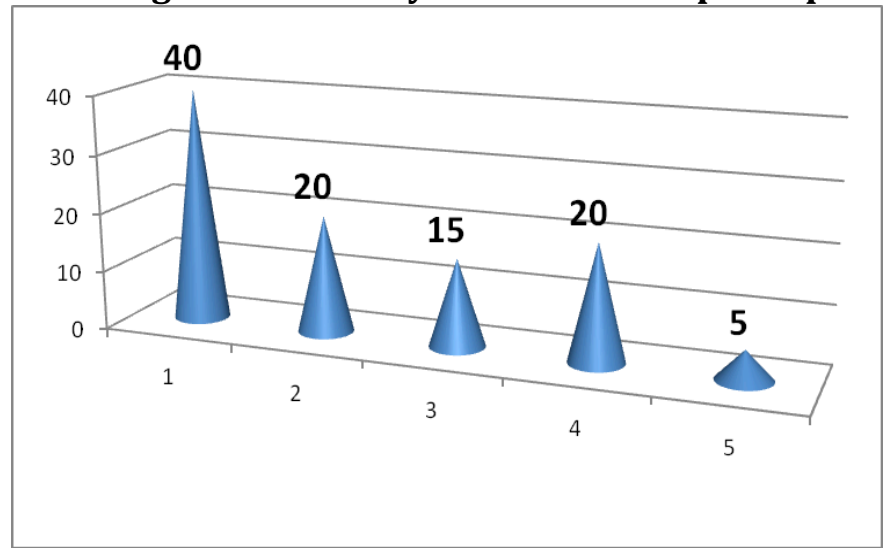

Source: Sample Survey December 2017 Figures in Per Cent only

Here in Y axis represent series 1 with Monthly Income up to USD 10,000 series 2 with Monthly Income between USD 10,001-20,000 series 3 with Monthly Income between USD 20,001-30, 000 series 4 with Monthly Income between USD 30,001-40,000 and series 5 with Monthly Income Above USD 40000.

\section{Customer Perception on Mobile marketing communication Versus Demographic characteristics such as Gender, Age and Marital Status.}

An attempt is made by authors of this study to check if there is any relationship between customer perception on mobile marketing communication and the demographic characteristics such as gender, age and marital status of the respondents using t-test and OneWay ANOVA (F test). 


\section{Customer perception on Mobile marketing communication versus Gender}

The Independent sample t test was carried out to check whether differences in customer perception on mobile marketing communication exist across the Gender of the respondents. The following hypotheses were formulated to check whether all genders had equal customer perception on mobile marketing communication or not.

H0: The customer perception on mobile marketing communication did not vary with Gender (Null Hypothesis)

H1: The customer perception on mobile marketing communication did vary with Gender (Alternative Hypothesis)

The Independent sample t test result shown below in Table 2.

Table 2 Result Of Independent Samples t Test Between Customer Perception On Mobile Marketing Communication And Gender

\begin{tabular}{|l|l|l|l|l|l|l|}
\hline $\begin{array}{l}\text { Customer } \\
\text { Experience }\end{array}$ & \multicolumn{2}{|l|}{ Levene's Test for Equality of Variance } & \multicolumn{4}{|c|}{ T test for Equality of Means } \\
\hline & F & Sig. & T & Df & $\begin{array}{l}\text { Sig. } \\
(2 \text { tailed })\end{array}$ & $\begin{array}{l}\text { Mean } \\
\text { Difference }\end{array}$ \\
\hline Gender & 0.008 & 0.927 & -1.719 & 1499 & 0.086 & -0.11918 \\
\hline
\end{tabular}

Source: Sample Survey December 2017

The results $(F(2,1500)=0.008, p>0.01)$ showed that there was no significant difference in customer perception on mobile marketing communication based on the gender of the respondent among neighborhood communities thereby accepting the null hypothesis.

\section{Customer perception on Mobile marketing communication versus Age}

One way ANOVA was used to test for differences in customer perception on mobile marketing communication across different age groups. The following hypotheses were formulated to check whether all age group of customers had equal customer perception on mobile marketing communication or not.

H0: The customer perception on mobile marketing communication did not vary for different Age groups (Null Hypothesis)

H1: The customer perception on mobile marketing communication did vary for different Age groups (Alternative Hypothesis)

Table 3 Result Of Anova Between Customer Perception On
Mobile Marketing Communication And Age
\begin{tabular}{|l|l|}
\hline Age group & $\begin{array}{l}\text { Customer Perception on } \\
\text { Mobile marketing } \\
\text { Communication } \\
\text { (Mean score) }\end{array}$ \\
\hline $19-29$ & 4.8973 \\
\hline $30-39$ & 4.7214 \\
\hline $40-49$ & 4.6740 \\
\hline $50-99$ & 4.4058 \\
\hline $60-69$ & 4.2304 \\
\hline F value: 6.821 & P= 0.000 \\
\hline Source: Sample Survey December $\mathbf{2 0 1 7}$ \\
\hline
\end{tabular}

The Table 3 showed that there was significant difference $(F(5,1500)=6.821, p<0.01)$ in customer perception on mobile marketing communication based on respondent's age groups thereby rejecting the null hypothesis. Based on the mean values for the different age groups, it 
can be seen that as age increases the customer perception on mobile marketing communication decreases. This may be attributed to the fact that younger respondents look at technology enabled shopping as a hedonic and experiential activity whereas the older respondents mainly focus on finishing their weekly offline shopping directly from the neighborhood shops and are not much interested to spend more time in their mobile phones by reading messages and posting in the social media sites.

\section{Customer perception on Mobile marketing communication versus marital status}

One way ANOVA was done to test for differences in customer perception on mobile marketing communication across different marital status groups. Therefore, the following hypotheses were formulated to check whether all groups of customers had equal customer perception on mobile marketing communication or not.

H0: The customer perception on mobile marketing communication did not vary for different marital status groups (Null Hypothesis)

H1: The customer perception on mobile marketing communication did vary for different marital status groups (Alternative Hypothesis)

Table 4 Result Of Anova Between Customer Perception On
Mobile Marketing Communication And Marital Status
\begin{tabular}{|l|l|}
\hline Marital status & $\begin{array}{l}\text { Customer Perception on } \\
\text { Mobile marketing } \\
\text { Communication } \\
\text { (Mean score) }\end{array}$ \\
\hline Married & 4.8973 \\
\hline Unmarried & 4.7214 \\
\hline Others & 4.6740 \\
\hline F value : 20.745 & $\mathbf{P}=\mathbf{0 . 0 0 0}$ \\
\hline Source: Sample Survey December $\mathbf{2 0 1 7}$ \\
\hline
\end{tabular}

Table 4 showed that there was significant difference $(F(2,1500)=20.745, p<0.01)$ in customer perception on mobile marketing communication based on marital status of the respondent thereby rejecting the null hypothesis. Based on the mean values of the different groups , it can be seen that unmarried respondents have better and positive perception towards mobile marketing communications than the married respondents. This may be attributed to the fact that unmarried respondents usually spend more time for social media and mobile marketing communications and they shop mainly for intrinsic enjoyment rather than to solve problems by purchasing products/services from Neighborhood stores.

\section{Detailed analysis of Consumer Perception on Mobile marketing communication}

It was observed from the data that $71 \%$ of respondents of this research were male and $29 \%$ were female. It showed that males were interested more in mobile marketing and using their mobile phones for shopping through social media sites as compared to female. Male respondents were actively participated in the online survey and responded to all questions promptly. Besides $99 \%$ of participants of the study whose cell phones were smart phones with uninterrupted internet access on a $24 X 7$ day basis. It is analyzed from the data collected during the study that $29 \%$ of respondents ignored the mobile marketing advertisements. On the other hand, $39 \%$ only read the advertisements in their mobile phone while $32 \%$ with them read and open the link or call the number after receiving the advertisement. Therefore, it is important for the SMEs and Neighborhood stores that their mobile advertisement should be attractive and grab the attention of customers. If advertisement which customers receive a message, 
email or notification, it should be more interesting so that people go through the link or follow up with the ads. People who are not interested in buying the products and services, they do not focus on advertisements and try to avoid them.

Compared with conventional retail shopping, the information environment of virtual shopping is enhanced by providing additional product information such as comparative products and services, as well as various alternatives and attributes of each alternative and so on (Jarvenpaa SL and Todd PA,1997). It was analyzed during the study that 59\% of respondents are influenced by the mobile marketing advertisements which they have viewed on social media on their cell phone. On the other hand, 21\% of respondents influenced through the Email Ad while 9\% from SMS and 8\% from Television. The radio and newspaper Ads affects further rest of the respondents with $2 \%$ and with $1 \%$ respectively. This result showed that social media sites played a significant role as most of the customers are using it for receiving ads as compared to other methods employed in the mobile marketing. Ads which were given on Facebook, Twitter, YouTube and other social networking sites lead to attract the customers' attention and encourage them to buy the products and services. Therefore, it was analyzed that social media highly influenced the customers purchase intent and got their attention very efficiently during their shopping.

Online stores are usually available 24 hours a day, and most of the respondents have Internet access both at work and at home. Visiting a conventional retail store requires travel or commuting and costs such as gas, parking, or bus tickets, and must typically take place during business hours. In this context the authors explored the respondents perception on the marketing effectiveness of mobile marketing communications. Here it was observed that 39\% of respondents who stated that upto 25 percent of the time customers viewed mobile marketing and followed through with purchasing the products through the using of their mobile phones. On the other hand, 33\% of them were of the viewed that they viewed mobile marketing and follow through with purchasing up to $50 \%$ of their purchasing.

Moreover, $15 \%$ of the respondents agreed that they viewed mobile marketing advertisements and follow through with purchasing of products through the using of their mobile phone up to 75\%. It means that People were more attracted toward the SMEs and Neighborhood stores products and services. If the ads were attractive then, it would influence the customers' decision and make them easily purchase products and services from the stores. Also, if the ads were engaging, customers would simply make a purchase of the SMEs and Neighborhood stores products and services. Additionally, SMEs and Neighborhood stores can effectively promote their products and services on the social networking sites through attractive offers during lean periods.

It was inferred from the study that mobile marketing play significant roles with respect to keep up-to-date about products and services that many of the customers are interested in. Therefore, SMEs and Neighborhood stores need to provide upto date information about their products and services through mobile marketing so that it can attract and retain a large number of profitable and loyal customers. People are interested in information which is provided on the mobile marketing advertisement. This is because it helps them in making purchase decisions and shopping list quickly. Up to date information help them to search and compare their offers with brand and price and also screen the message credibility and bait advertisements

The popularity of online shopping continues to erode sales of conventional retailers. It showed that $23 \%$ respondents were strongly agreed and $41 \%$ of respondents were agreed that mobile 
marketing enabled them to search and compare different products and services. Hence, it shows that there mobile marketing is effective as it plays a significant role in making purchase decisions. It is so because people are using it for making a comparison in different company's product in terms of cost, quality and delivery time. Then they make a decision of purchase. On the other side, it also helps them in getting knowledge which SMEs and Neighborhood store is providing an attractive offer on products and the way they are responding to the customers. These facilities encourage customers to make a purchase easily with the use of social media from their mobile phones. Again, $40 \%$ of respondents are strongly agreed and $13 \%$ of them are agreed that Social Media is a great place for SMEs and Neighborhood stores to increase engagement with consumers. Hence, SMEs and Neighborhood stores should use social media to attract their customers' attention toward their products and services and make them informed about arrival of new products and update models.

Attractive message with unique content helps SMEs and Neighborhood stores pull customers to respond to their offers and messages. Further, $41 \%$ of respondents were strongly agreed, and $23 \%$ of them were only agreed that the availability of social media from their mobile phones have made them more informed about brands while shopping online and offline. It may be noted that $62 \%$ of respondents spend more than one third of their active time in a day on social media from their mobile phones. Further 31\% of respondents were agreed that they spend maximum of $30 \%$ of their day on the mobile phone. The result, explained that mobile phones become one of the important needs of people around the world. With the use of social media, they can communicate with their friends and be informed and knowledgeable about a product which they want to buy. The new features of mobiles are helpful for the customers to make a purchase through handsets and websites. Therefore, it is essential for the SMEs and Neighborhood stores to lure the customers through posting attractive ads.

\section{Relationship between various Determinants and Marketing effectiveness of Mobile marketing communication}

It may be noted that Multiple Regression which is an extension of Simple Linear Regression were resorted by the authors to predict the value of a dependable variable (marketing effectiveness of mobile communication) based on the value of other six independent variables. In order to study the relationship between the various independent variables/determinants and the marketing effectiveness on mobile marketing communication, multi-item scales were used. Prior to this analysis internal consistency of the independent variables were checked through Cronbach alpha values for the constructs and presented in Table-1 section 4.1 of this paper. It is established from the Table- 1 that the values were in the range 0.789 to 0.896 which indicated that the instruments were reliable. Subsequently multiple regression analysis was performed to make the significance on the determinants of marketing effectiveness of mobile marketing communication among neighborhood communities in USA.

\section{Regression Analysis}

The generalized equation for regression is

$\mathrm{ME}=\mathrm{a}+\beta 1 \mathrm{MCR}+\beta 2 \mathrm{SCP}+\beta 3 \mathrm{MAE}+\beta 4 \mathrm{RES}+\beta 5 \mathrm{REL}+\beta 6 \mathrm{ASS}$

Where

ME is Marketing Effectiveness of Mobile marketing communication

MCR is Message content and its relevancy to weekly shopping

SCP is Search and compare products, price \& brands online

MAE is Mobile marketing message credibility, authenticity and Empathy 
RES is Responsiveness

REL is Reliability and

ASS is Assurance

Table 5 : Descriptive Statistics Of Variables Under Study

\begin{tabular}{|l|l|l|l|}
\hline VARIABLE & SAMPLE SIZE & MEAN & $\begin{array}{l}\text { STANDARD } \\
\text { DEVIATION }\end{array}$ \\
\hline $\begin{array}{l}\text { 1. Search and compare products, price \& brands online (SCP) } \\
\text { 2. Mobile marketing message content and its relevancy to weekly } \\
\text { shopping (MCR) }\end{array}$ & 1500 & 3.5580 & 1.28473 \\
\hline 3. Responsiveness (RES) & 1500 & 4.5725 & 1.35096 \\
\hline $\begin{array}{l}\text { 4. Mobile marketing message credibility, authenticity and Empathy } \\
\text { (MAE) }\end{array}$ & 1500 & 2.2536 & 0.74043 \\
\hline 5.Assurance (ASS) & 1500 & 3.4594 & 1.10900 \\
\hline 6.Reliability (REL) & 1500 & 2.0543 & 1.53136 \\
\hline
\end{tabular}

Source: Sample survey December 2017

The Regression model and its related $\beta$ estimates as shown in Table 6 given below indicate that Message content and its relevancy to weekly shopping, Message credibility, authenticity and Empathy, Reliability and Search and compare products, price \& brands are significant in predicting marketing effectiveness of the mobile marketing communication.

Table 6: predictor effects and $\beta$ eta estimates for determinants on marketing effectiveness

\begin{tabular}{|l|l|l|l|l|l|}
\hline \multicolumn{1}{|c|}{ Model } & \multicolumn{2}{l|}{ Unstandardized Coefficients } & $\begin{array}{l}\text { Standardized } \\
\text { Coefficients }\end{array}$ & t & Sig. \\
\hline \multicolumn{1}{|c|}{ Constant } & $\begin{array}{l}\text { a } \\
\mathbf{0 . 7 9 3}\end{array}$ & $\begin{array}{l}\text { Std. Error } \\
0.286\end{array}$ & Beta & 2.861 & 0.005 \\
\hline $\begin{array}{l}\text { Search and compare products, } \\
\text { price \& brands (SCP) }\end{array}$ & 0.173 & 0.049 & 0.218 & 3.336 & 0.001 \\
\hline $\begin{array}{l}\text { Message credibility, } \\
\text { authenticity and Empathy } \\
\text { (MAE) }\end{array}$ & 0.448 & 0.084 & 0.492 & 6.438 & 0.000 \\
\hline Assurance (ASS) & & & -0.004 & -0.025 & 0.964 \\
\hline Reliability (REL) & -0.002 & 0.084 & 0.184 & 2.135 & 0.003 \\
\hline Responsiveness(RES) & 0.171 & 0.092 & -0.025 & -0.546 & 0.580 \\
\hline $\begin{array}{l}\text { Message content and its } \\
\text { relevancy to weekly shopping } \\
\text { (MCR) }\end{array}$ & -0.032 & 0.078 & 0.193 & 2.348 & 0.019 \\
\hline
\end{tabular}

Source: Sample survey December 2017

The adjusted Regression equation for determining marketing effectiveness of mobile marketing communication is stated as

$$
\mathrm{ME}=0.79+0.22 \mathrm{SCP}+0.49 \mathrm{MAE}+0.18 \mathrm{REL}+0.19 \mathrm{MCR}
$$

Where ME is Marketing Effectiveness, SCP is Search and compare products , price \& brands, MAE is Message credibility, authenticity and Empathy, REL is Reliability and MCR is Message content and its relevancy to weekly shopping

\section{Model Significance}

As shown in Table 6 Search and compare products, price \& brands (SCP) was significantly influenced marketing effectiveness $(\beta=0.218, p<0.05)$. Further Message credibility, 
authenticity and Empathy (MAE) significantly influenced marketing effectiveness ( $\beta$ $=0.492, \mathrm{p}<0.05$ ) and it is the strongest determinant of marketing effectiveness of mobile communication. Reliability is significantly influencing customer marketing effectiveness ( $\beta$ $=0.184, \mathrm{p}<0.05$ ) and finally Message content and its relevancy to weekly shopping was significantly influencing marketing effectiveness $(\beta=0.193, p<0.05)$.

Further, the Regression residue distribution is checked for normality by using Histogram and PP chart and found to be satisfactory as in figure 4 and 5. The regression variate is found to meet the assumption of normality.

Figure 4 Residue Distributions Of Marketing Effectiveness

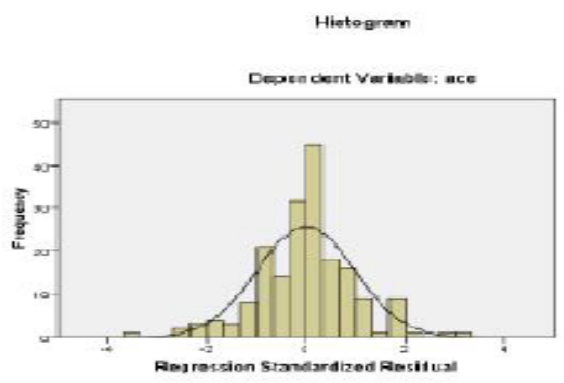

Source: Sample Survey December 2017

Figure 5 P-P Plot Residue Distributions Of Marketing Effectiveness

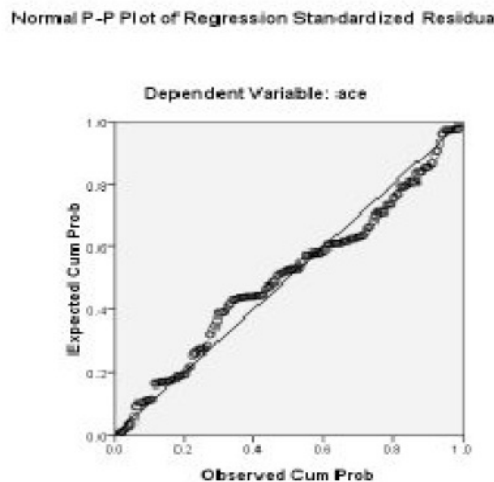

Source: Sample Survey December 2017

Table 7 Summary Of Regression: Models For Determinants With Mean Square Residual Values

\begin{tabular}{|l|l|l|l|l|l|}
\hline \multicolumn{1}{|c|}{ Model } & Sum of Squares & df & Mean Square & F & Sig. \\
\hline Regression & & & & & \\
\hline Residual & 568.373 & 5 & $\mathbf{7 1 , 0 4 8}$ & 262.44 & 0.000 \\
\hline Total & 365.468 & 1350 & $\mathbf{2 . 0 3 3}$ & & \\
\hline
\end{tabular}

Source: Sample Survey December 2017

The results of the Multiple Regression using stepwise method as in Table 7 and 8 showed that overall model for the marketing effectiveness of mobile communications, This regression analysis has yielded a significant statistic $(\mathrm{F}=262.44, \mathrm{p}<0.000)$ and adjusted $\mathrm{R}$ square 0.591 , explained by mobile marketing content, message credibility, authenticity, its relevancy to weekly shopping, Search and compare products, price \& brands along with human supports through chats and customer service (empathy), consistent quality and performance ( Reliability) significantly influenced the marketing effectiveness. 
Table 7 Summary Of Regression: Model For Determinants And Marketing Effectiveness

\begin{tabular}{|l|l|l|l|l|}
\hline Model & R & R Square & Adjusted R Square & Std.Error of the Estimate \\
\hline 1 & 0.780 & 0.609 & 0.591 & 0.52030 \\
\hline
\end{tabular}

Source: Sample Survey December 2017

It is clearly established from the Multiple Regression analysis that by focusing on mobile marketing content, message credibility, authenticity, its relevancy to weekly shopping along with human supports through chats and customer service ( empathy) and consistent quality and performance ( Reliability) can give an edge to the SMEs and Neighborhood stores over national and global brands in their neighborhoods. It is important to mention here that Assurance (ASS) and Responsiveness(RES) were not considered significant determinants in the marketing effectiveness of mobile marketing communication. This is because of US law brings a lot of protection for privacy of customer data and the rights of consumers while shopping online and offline.

\section{MAJOR DISCUSSIONS AND IMPORTANT FINDINGS}

The major advantage of shopping online is being able to quickly seek out deals for items or services provided by many different vendors (though some local search engines do exist to help consumers locate products for sale in nearby stores). Search engines, online price comparison services and discovery shopping engines can be used to look up sellers of a particular product or service (Novak Thomas P, Donna L Hofmann and Yiu-Fai Yung, 2000) . According to the multiple regression analysis, it was found that Social media ads were influenced respondents while making their shopping list and purchases. Also mobile marketing content, message credibility, authenticity, its relevancy to weekly shopping along with human supports through chats and customer service (Empathy) and consistent quality and performance (Reliability) can make the respondents more frequent shoppers and loyal to SMEs and neighborhood stores. These findings are consistent with literature review and it was established that through social media and mobile marketing, SMEs and neighborhood stores can connect with their customers with latest updates on new product arrivals, price discount, and weekly bundles of product at discounted prices .

Moreover, respondents of the study became more familiar with the mobile phones as they used it every day for multipurpose/multi tasking such as calling, texting, browsing and buying or selling products or services. It seems the mobile phones are their dearest friend and companion always even during sleeping. Also, with respect to save the time and money, most of the respondents preferred to go through with mobile ads as it helps them choosing a good deal with a quality product/brand and making a shopping list at the end. On Facebook, Twitter, and companies' websites respondents of the study always received different choices for their weekly purchases and they have the ability to choose the trusted SMEs and neighborhood stores from their own previous purchase experience.

One of the great benefits of online shopping is the ability to read product reviews, written either by experts or fellow online shoppers Karjaluoto (Shajahan S 2006 and Heikki \& Leppäniemi Matti, 2005).Furthermore, the findings from literature review shed light on many offers which customers received on their mobile phones such as flat $20 \%$ to $80 \%$ off on MRP on product which encouraged customers to visit their website and make a purchase. Additionally, research findings showed that respondents received more than 15 to 25 mobile marketing ads message on their mobile phone which influence them to make a purchase. On a critical note, there were different types of mobile marketing which were benefiting the customers such as SMS and MMS marketing, Push notification, Ringless voice message, App based marketing and Location based services. The marketing effectiveness of such mobile 
marketing communications showed the consistency with the findings of the literature survey and secondary research undertook for the purpose of the study.

\section{IMPLICATIONS OF THE STUDY}

The study would enable SMEs and Neighborhood store owners, managers, salespersons and researchers to gain better understanding of the impact of independent variables that would influence marketing effectiveness of the mobile marketing campaigns and communication messages on social media. This in turn, will improve their MROI and create a positive business outcome in USA. A complete understanding of the various determinants that were used in this study would enable the SMEs and Neighborhood stores in USA to create a memorable experience for the customer while shopping online or in the outlet. This study contributes to the volume of modern literature on determinant of marketing effectiveness of mobile marketing communications on social media for Neighborhood stores in the US scenario. The managerial contribution of the study provides a base for the modern neighborhood stores who want to understand the key drivers of predicting marketing effectiveness of mobile marketing communications on social media and if required, they would modify their marketing communication strategies accordingly to provide a better experience during online and instore shopping in USA.

\section{SUMMARY AND RECOMMENDATIONS}

The findings of this study helped in developing deeper understanding of the factors that influenced the marketing effectiveness of mobile marketing communications, its contribution to Marketing Return On Investment(MROI) and the way it influenced customers purchase decisions in USA. It was observed that online reviews, peer recommendations on online shopping pages or social media websites played a significant role for shoppers when they were planning weekly online and instore shopping. It was also concluded from the findings of the study that most of the respondents were using the mobile phone for shopping based on the mobile marketing messages posted in the social media. Implementation of new technology in the mobile phone helped companies to market their products and customers can easily shop online or instore. It was also noticed that there were an upcoming trend of mobile marketing through the social media in USA. This is because customers were getting benefits from the mobile phones and mobile marketing communications as they can comfortably purchase any products and services from any place and at any time. Most importantly, nearly $99 \%$ of the shopping of the respondents were influenced by social media during the period of the study.

It was concluded from the finding of the study that through effective mobile marketing, SMEs and Neighborhood stores were able to build and retained a positive sustained relationship with their customers. Many SMEs and Neighborhood stores under study were using mobile marketing communications for the purpose of communicating their latest product arrival and ongoing offers/discount news with their customers. By predicting marketing effectiveness SMEs and Neighborhood stores can improve their MROI and foster a favourable customer attitude and better perception towards their products and mobile marketing communication. From the data analysis, it was observed that respondent used more than $30 \%$ of a day on their mobile phones for checking social media postings. In order to understand the customers' attitudes and perceptions towards the use of social media as a marketing tool, it was concluded that nearly 80 percent of the respondents who avoid the ads which they had no relevance to their shopping list and interest. Hence the study finding of predicting marketing effectiveness and improving MROI were found to be the most significant to the service providers online and instore. 
Finally, this research study focused only on the perception of the neighborhood communities and customers of three western states of USA. Hence the study findings reflected only the perceptions of the neighborhood population. In summary, customers' responses resulting in positive emotional reactions in the form of likes, Forwards, Comments and Customer Reviews as a feedback of mobile marketing communication on social media were increasingly being seen as real and sustainable differentiator between competing neighborhood stores under study. Further, Proximity marketing is a relatively new phenomenon in USA and hence research is required to understand the determinants of marketing effectiveness of proximity marketing communication that would help the retailers and neighborhood stores to comprehend the MROI and Customer Relationship Management.

\section{ACKNOWLEDGEMENT}

Authors would sincerely thank Prof. Cheryl Luczak Director Center of Service Excellence, Prof. Faisal Rahman Dean and Mr.Bruce Lipman Director Graduate Programs of Saint Xavier University ,Graham School of Management , which is located in City of Chicago in the Mt. Greenwood neighborhood on the corner of 103rd Street and Central Park Avenue USA, for providing us immense support and guidance while carrying out this research. We would like to express our gratitude towards the Academic Staff and Students of Graham School of Management ,Colleagues, Friends and Family members who assisted and participated in the research in USA despite their official, personal and professional commitments . We also acknowledge the support of DR Hassan Almahdi Dean CBA, DR Shafeeq M. Assiri Vice Dean and Head of the Dept. of Marketing \& E Commerce College of Business Administration, Jazan University , Ministry of Higher Education KSA for publishing this work

\section{References \\ Website}

https://www.amazon.com/Books-S-

Shajahan/s?ie=UTF8\&page=1\&rh=n\%3A283155\%2Cp_27\%3AS.\%20Shajahan

http://www.gsma.com/mobileeconomy (for book The Mobile Economy 2017' authored by GSMA Intelligence, the Research arm of the GSMA)

\section{Books And Research Journals}

Abhishek Borah Gerard J Telli and Halo, “(Spillover) Effects in Social Media: Do Product Recalls of One Brand Hurt or Help Rival Brands?” Journal of Marketing Research 53:2, Apr-2016.

American Productivity \& Quality Center(AP\&QC), Maximizing Marketing ROI American Productivity Center. ISBN 1-928593-57-7, 2001.

Banerjee, Syagnik (Sy) and Dholakia, Ruby Roy," Mobile Advertising: Does Location Based Advertising Work?" International Journal of Mobile Marketing, December 2008.

Briggs, Rex, Stuart, Greg, What Sticks: Why Most Advertising Fails and How to Guarantee Yours Succeeds Kaplan Business. ISBN 1-4195-8433-2, 2006.

Bigne, Enrique, "The Impact of Internet User Shopping Patterns and Demographics on Consumer Mobile Buying Behavior" (PDF). Journal of Electronic Commerce Research. 6(3). 2005.

Cleff, Evelyne Beatrix, "Privacy issues in mobile advertising" British and Irish Law, Education and Technology Association, Annual Conference Hertfordshire, 2007.

Guo S, Wang M, and Leskovec J," The Role of Social Networks in Online Shopping: Information Passing, Price of Trust, and Consumer Choice", ACM Conference on Electronic Commerce, 2011.

Gaughan L, Mobile Marketing a Tool for Building Customer Loyalty. Retrieved from Letterkenny Institute of Technology, 2012

Hsiao, Ming-Hsiung. "Shopping mode choice: Physical store shopping versus e-shopping". Transportation Research Part E: Logistics and Transportation Review. 45 (1): doi:10.1016/j.tre.2008.06.002, 2009. 
Hair, Joseph, F., Rolph E. Anderson, Ronald L. Tatham and William C. Black, Multivariate Data Analysis, 6th ed., Englewood Cliffs, NJ: Prentice Hall, 2006.

Henning Jeffrey "Multi-Item Scale (Index) Construction in Survey Research" Posted by Jeffrey Henning on Fri, Mar 20, 2009 http://blog.vovici.com/blog/bid/18157/Multi-Item-Scale-Index-Construction-in-Survey-Research.

Jarvenpaa, S. L.; Todd, P. A. "Consumer reactions to electronic shopping on the world wide web". International Journal of Electronic Commerce. 1997, doi:10.1080/10864415.1996.11518283.

Karjaluoto Heikki and Leppäniemi Matti, "Factors influencing consumers' willingness to accept mobile advertising: a conceptual model", International Journal of Mobile Communications, Vol 3, No. 3, 2005.

Kaplan, Andreas "If you love something, let it go mobile: Mobile marketing and mobile social media 4x4 Found", Business Horizons, 55(2), 129-139, 2012.

Kawai, F; Tagg, $S$. "The construction of online shopping experience: A repertory grid approach". Computers in Human Behavior. 72: 222-232. doi:10.1016/j.chb.2017.02.055, July 2017.

Kannan, P. K; Alice Li, Hongshuang "Digital Marketing: A framework, review and research agenda". International Journal of research in Marketing. 34 (1): 22-45. doi:10.1016/ji.ijresmar.2016.11.006, 2017.

Kahn, A.J. Service delivery at the neighborhood level: Experience, theory and fads. Social Service Review, 50(1): 23-56, 1976

Kim Y H, Kim J \& Wachter, "A study of mobile user engagement (MoEN): Engagement motivations, perceived value, satisfaction, and continued engagement intention", Decision Support Systems, 56, 2013.

Leppäniemi, Matti, "Mobile marketing communications in consumer markets", Faculty of Economics and Business Administration, Department of Marketing, University of Oulu, 2008, p. 21.

Lamberton C \& Stephen A T, "A thematic exploration of digital, social media, and mobile marketing: Research evolution from 2000 to 2015 and an agenda for future inquiry", Journal of Marketing, 80(6), 2016.

Lenskold, James, Marketing ROI: The Path to Campaign, Customer, and Corporate Profitability, McGraw-Hill, ISBN 007-141363-4, 2003.

Malhotra, Naresh and David Birks, Marketing Research: An applied approach: 3rd European Edition. Pearson Education, 2007.

Nunnally, J.C. Psychometric Theory, New York: McGraw-Hill,1967.

Nunnally, J.C. and Berstein, I.H. Psychometric Theory. New York: McGraw-Hill, 1994.

Novak, Thomas, P., Donna L. Hofmann and Yiu-Fai Yung, "Measuring the Customer Experience in Online Environments: A Structural Modeling Approach," Marketing Science, Vol.19, No. 1,pp.22-4, 2000.

Pappas, N "Marketing Strategies perceived risks, and consumer trust in online behaviour". Journal of Retailing and Consumer Services. 29: 92-103. doi:10.1016/i.jretconser.2015.11.007, March 2016.

Parker, Christopher J.; Wang, Huchen "Examining hedonic and utilitarian motivations for m-commerce fashion retail app engagement". Journal of Fashion Marketing and Management. 20(4): 487. doi:10.1108/JFMM-02-2016$\underline{0015}, 2016$.

Peterson, R. A.; Balasubramanian, S.; Bronnenberg, B. J. "Exploring the implications of the Internet for consumer marketing". Journal of the Academy of Marketing Science. 25: 329-346. doi:10.1177/0092070397254005, 1997.

Powell, Guy R., Return on Marketing Investment: Demand More From Your Marketing And Sales Investments RPI Press. ISBN 0-9718598-1-7, 2003.

Rohm, Andrew J; Swaminathan, Vanitha ."A typology of online shoppers based on shopping motivations". Journal of Business Research. Marketing on the web - behavioral, strategy and practices and public policy. 57 (7): 748757. doi:10.1016/S0148-2963(02)00351-X m, 2004

Shajahan S, "Micro-profiling of shopping mall customers' in Chennai" ,Paradigm, IMT, Ghaziabad , December 2001.

Shajahan S , Marketing Research- Text and cases, Macmillan Publishers Limited, ISBN-10: 1403925011, ISBN13: $9781403925015,2004 a$.

Shajahan S, "Micro-profiling of cola customers " ICFAI Journal of Marketing Mastermind, Hyderabad , August 2004b. 
Shajahan S, "Private labels in Retailing industry", ICFAI Journal of Marketing Mastermind, Hyderabad, April 2004c.

Shajahan S, "Happy price- happy shopping campaign analysis for Foodworld”, ICFAI Journal of Marketing Mastermind, Hyderabad, March 2005.

Shajahan S, Relationship Marketing -Concepts and Cases, McGraw-Hill Europe, ISBN-10: 0070583374 ISBN-13: 978-0070583375, 2006

37.Shajahan S, Business Research Methods, Jaico Publications , ISBN-10: 8184950330 ISBN-13: 978-8184950335 , 2009

ShajahanS, ,Strategic Marketing -Text and Cases, Viva Books, ISBN-10: 8130912694, ISBN-13: 978-8130912691, 2010

hajahan S, Research Methods for Management ,4th Edition, Jaico Publications, ISBN-10: 8172244916,ISBN-13: 978$8172244910: 2011$

Shajahan S, Services Marketing --Text and Cases, $4^{\text {th }}$ Edition, Himalaya Publishing House, ISBN-10 : 8183183719 , ISBN-13: 978-8183183710, 2016.

Shajahan S, "A Study on the Impact of Situational and Customer Moderators on the Determinants of Customer Experience among Supermarket Shoppers in Saudi Arabia" International Educational Applied Scientific Research Journal ISSN (Online): 2456-5040 Volume: 1 | Issue: 2 | November 2016

Shajahan S, "A Study on the determinant of customer experience among Supermarket shoppers in Saudi Arabia”, PYREX Journal of Business and Finance Management Research, ISSN 2985-8860 Vol.12, Issue 1, January 2017a.

Shajahan S, "A Study on the Impact of Situational and Customer Moderators on the Determinants of Customer Experience among Hypermarket Shoppers in Saudi Arabia”, IMPACT: International Journal of Research in Business Management (IMPACT: IJRBM) ISSN(P): 2347-4572; ISSN(E): 2321-886X,Vol. 5, Issue 2, Feb 2017b

Shajahan S, "A Study on the Determinant of Customer Experience among Hypermarket Shoppers in Saudi Arabia” , MERC Global's International Journal of Social Science \& Management, ISSN 2348-5620 ,Volume 4, Issue 2, May 2017c.

Shaw, R. Improving Marketing Effectiveness - the methods and tools that work best, Economist Books, ISBN $\underline{1-}$ 86197-054-4, 1998.

Shankar V, Kleijnen M, Ramanathan S, Rizley R, Holland., \& Morrissey, "Mobile shopper marketing: Key issues, current insights, and future research avenues", Journal of Interactive Marketing, 34, 2016.

Sherry Y. Chen en Robert D. Macredie, "The assessment of usability of electronic shopping: A heuristic evaluation", International Journal of Information Management 2005

Ström R, Vendel M \&Bredican J "Mobile marketing: A literature review on its value for consumers and retailers” Journal of Retailing and Consumer Services, 21(6), 2014.

Thompson and Donald L. "Consumer Convenience and Retail Area Structure," Journal of Marketing Research, Vol.4 pp.37-44, February 1967.

Watson C, McCarthy J \& Rowley J, “Consumer attitudes towards mobile marketing in the smartphone era”. International Journal of Information Management, 33(5), 2013.

Yadav, M, Joshi, Y, \& Rahman, Z Mobile social media: "The new hybrid element of digital marketing communications", Procedia-Social and Behavioral Sciences, 189, 2015.

Zaichkowsky and Judith Lynne, "Measuring the Involvement Construct," Journal of Consumer Research, December 1985. 